Revue Française de Civilisation Britannique

XXII-1 | 2017

The Book of Common Prayer : Studies in Religious Transfer

\title{
The Penitential Psalms and Ash Wednesday Services in the Book of Common Prayer, 1549-1662
}

Les psaumes pénitentiels et les offices du mercredi des Cendres dans le Book of Common Prayer, 1549-1662

\section{Charles Whitworth}

\section{OpenEdition \\ Journals}

Electronic version

URL: http://journals.openedition.org/rfcb/1222

DOI: $10.4000 / \mathrm{rfcb} .1222$

ISSN: 2429-4373

Publisher

CRECIB - Centre de recherche et d'études en civilisation britannique

Electronic reference

Charles Whitworth, « The Penitential Psalms and Ash Wednesday Services in the Book of Common

Prayer, 1549-1662 », Revue Française de Civilisation Britannique [Online], XXII-1 | 2017, Online since 02 May 2017, connection on 19 April 2019. URL : http://journals.openedition.org/rfcb/1222 ; DOI :

$10.4000 /$ rfcb. 1222

This text was automatically generated on 19 April 2019

\section{cc) () $\odot$}

Revue française de civilisation britannique est mis à disposition selon les termes de la licence Creative Commons Attribution - Pas d'Utilisation Commerciale - Pas de Modification 4.0 International. 


\title{
The Penitential Psalms and Ash Wednesday Services in the Book of Common Prayer, 1549-1662
}

\author{
Les psaumes pénitentiels et les offices du mercredi des Cendres dans le Book of \\ Common Prayer, 1549-1662
}

Charles Whitworth

1 Book of Common Prayer, psaumes pénitentiels, liturgie, Carême

2 Beside the gradual, incremental process by which the English Church shifted from a Catholic to a reformed liturgy in Henry's and Edward's reigns, preserving some measure of experiential continuum, another aspect of liturgical continuity can be seen in the way in which the successive liturgical revisions, especially after 1552, sometimes introduced renewed closeness to medieval liturgical usage. The 1559 conservative revision of the words of administration of Holy Communion is a well-known example (see Claire Cross's paper in this volume), but there are other, more rarely studied examples. One is provided by the revisions of the Ash Wednesday liturgy and the fate of the penitential psalms. From the Sarum rite through the successive revisions of the Prayer Book up to 1662, the sense that the English liturgy has to some extent come full circle - away from the Middle Ages and then moving back a little closer to it - is striking.

After Morning Prayer, the Litany ended according to the accustomed manner, the Priest shall, in the Reading-Pew or Pulpit, say:

BRETHREN, in the Primitive Church there was a godly discipline, that, at the beginning of Lent, such persons as stood convicted of notorious sin were put to open penance, and punished in this world, that their souls might be saved in the day of the Lord; and that others, admonished by their example, might be the more afraid to offend.

Instead whereof, until the said discipline may be restored again, (which is much to be wished,) it is thought good, that at this time (in the presence of you all) should be read the general sentences of God's cursing against impenitent sinners ... and that ye should answer to every Sentence, Amen: To the intent that, being admonished of the great indignation of God against sinners, ye may the rather be 
moved to earnest and true repentance; and may walk more warily in these dangerous days; fleeing from such vices, for which ye affirm with your own mouths the curse of God to be due.

That is the beginning, in the Prayer Book of 1662, of the service of 'Commination, or denouncing of God's anger and judgements against sinners, with certain prayers, to be used on the first day of Lent, and at other times, as the Ordinary shall appoint'. It is still there today 350 years later, in just those words, in reprints of the Book of Common Prayer. The title for this special Ash Wednesday service, 'A Commination', from the Latin comminari, to threaten or menace (or in an ecclesiastical context, to anathematize), is first used in the second Edwardian Prayer Book of 1552. Indeed, that is the first occurrence recorded in OED of the word in its strict liturgical connotation. The explanatory gloss, 'or denouncing of God's anger and judgements against sinners', was added to the rubric in 1662. 1552 and 1559 just read 'A Commination against sinners, with certain prayers to be used divers times of the year'. On the other hand, 1549 does specify 'the first day of Lent, commonly called Ash Wednesday'; the first half of the phrase, 'the first day of Lent', was restored in 1662. Archbishop Grindal, in Elizabeth's reign, instructed that the service be used at least four times in the year. We might also note here that in the direction from 1662 quoted above, 'After Morning Prayer, the Litany ended ...', all the earlier books, 1549, 1552 , and 1559, specified 'the ENGLISH litany shall be read'; in 1662, there was no longer any need for such specificity: no other Litany could have been intended. We recall that Thomas Cranmer had produced an English litany in 1544, five years before the first Book of Common Prayer.

4 The celebration of the beginning of Lent, the season of fasting before Easter, and the anointment of penitents with ashes as a sign of humility, were a very ancient custom, dating from the time of the primitive church, as the opening sentence quoted above indicates. Gratian, the twelfth-century canon lawyer, describes the ceremony in his Concordia discordantium canonum:

On the first day of Lent, the penitents were to present themselves before the bishop, clothed with sackcloth, with naked feet, and with eyes turned to the ground; and this was to be done in the presence of the clergy of the diocese, who were to judge of the sincerity of their repentance. These introduced them into the church, where the bishop, in tears, and the rest of the clergy, repeated the seven penitential psalms. Then, rising from prayers, they threw ashes upon them, and covered their heads with sackcloth ... Then the bishop commanded the officers to turn them out of the church doors; and all the clergy followed after, repeating that curse upon Adam, In the sweat of thy brow shalt thou eat thy bread. The like penance was inflicted upon them the next time the Sacrament was administered, which was the Sunday following. ${ }^{1}$

We see here that the seven psalms were already-whatever the precise epoch in which the service described took place-an integral part of the Ash Wednesday liturgy.

By far the most widely used liturgy by the early sixteenth-century in England (and beyond), and the one preferred by Archbishop Cranmer, was the Use of Sarum (Salisbury). It was adopted by cathedral chapters as far north as Lincoln, and had spread to Wales, Scotland, Ireland, and even Portugal by the twelfth century. ${ }^{2}$ The Sarum Missal provides considerable detail about the Ash Wednesday rites-the ones that Cranmer would have had clearly in mind when he set about composing the service for the new Prayer Book of 1549. The English translation of the Sarum Missal demonstrates clearly the longstanding medieval practice, as Gratian recorded it, including the literal thrusting out of the penitents at the church door. But it is the opening rubric that is of immediate interest: " 
After Sexts there may be a sermon to the people. After which let the Clergy prostrate themselves in the choir and say the seven Penitential Psalms, with the anthem Remember not, Lord, our offences ... ${ }^{3}$ The seven Penitential Psalms had obviously been a fixed part of the Ash Wednesday liturgy since the early Middle Ages. Their inclusion was perpetuated in the successive versions of the Book of Common Prayer, though in various ways, as we shall see, one of many elements retained from the old Roman practice in the new Church of England service.

7 The designation of seven of the 150 psalms as a group, known as the Penitential Psalms, dates from the early centuries of the medieval church. It is far from certain who first proposed the grouping or why, or when they became commonly recognized and accepted as a discrete group. As early at least as Cassiodorus in the mid-sixth century, perhaps as early as the fifth, during the lifetime of St. Augustine (the designation is sometimes attributed to him), perhaps even the fourth (St. Ambrose) the Penitential Psalms were recognized as a group, though they are far from uniform in content or tone. ${ }^{4}$ The seven are, in the numbering of the Hebrew Psalter (Masoretic Text) and translations deriving from it, including the Great Bible and subsequent English versions: Psalms 6, 32, 38, 51, 102, 130, and 143 (the Septuagint and the Latin Vulgate counted Psalms 9 and 10 as one; hence the numbering from that point on is one less than in the Hebrew and its derivatives. E.g., 51 is 50, 130 is 129 , etc.). At the risk of over-determining, we may notice a certain symmetry in the apparently random choice of psalms in the group, despite their diverse forms and contents, if we consider the Latin titles, that is the first few words of each psalm, titles which are to this day given along with the number, in the Book of Common Prayer:

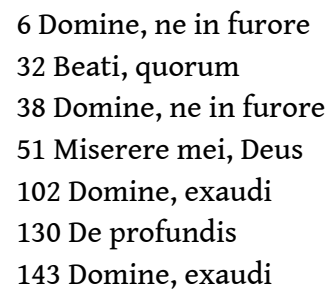

8 That is, two psalms beginning Domine, ne in furore frame the Beati quorum, and two others beginning Domine, exaudi frame the De profundis. The two triptychs in turn frame the central Miserere mei, Deus, the most famous and most often cited, quoted and paraphrased of the seven (and the one continuous presence among the seven in Ash Wednesday offices over the centuries). ${ }^{5}$ All four framing psalms begin with an address to God, Domine. Mere coincidence or a determining factor in the original designation of the seven psalms? One may be tempted to suspect the latter, given the medieval 'rage for order', the penchant for organizing, ordering, classifying, systematizing, evident in works of philosophy and theology as well as rhetoric and logic, so well described by C.S. Lewis. ${ }^{6}$

Both before and after the Reformation, paraphrases and commentaries on the seven psalms abounded. Gregory the Great in the sixth century was supposed to have composed a commentary (it is now considered spurious), and Alcuin of York in the eighth did compose one specifically on the Penitential Psalms. In the early fifteenth century, two distinguished women, in France and in England, wrote commentaries on them in their respective vernaculars: Christine de Pisan and Dame Eleanor Hull. ${ }^{7}$ Hull's is a translation from old French. Even earlier, in the first half of the fourteenth century, the prolific Yorkshire mystic Richard Rolle produced an English prose version of the entire psalter, with verse-by-verse commentary based on that of Augustine's Enarrationes. ${ }^{8}$ John Fisher, 
Bishop of Rochester and Chancellor of Cambridge University published his commentaries on the seven psalms in 1508; they were reprinted seven times in the next twenty years. Fisher was martyred for his opposition to Henry VIII in June 1535, just two weeks before his friend Sir Thomas More followed him on the scaffold. ${ }^{9}$ Later John Donne preached sermons on several of the Penitentials, and Lancelot Andrewes published devotional meditations on all seven.

Innumerable translations and paraphrases of the psalms in English were produced throughout the sixteenth century. The Reformation did nothing to dampen enthusiasm for the Old Testament poetry of David the poet-king (as it was generally believed that he was the author of all the psalms), including specifically the seven Penitentials, on the contrary. Martin Luther's favourite 'Pauline Psalms' were four of the Penitentials: 32, 51, 130,143 . Behind the impetus of Luther, whose commentary on the seven was published in 1517, and of Calvin's, then Clément Marot's and Théodore de Bèze's translations in the immensely influential Geneva Psalter, the psalms became even more widely read, translated, paraphrased, memorized, said and sung than ever before. Robert Crowley and Matthew Parker, Sir Philip Sidney and his sister Mary, Countess of Pembroke, and Sir John Harington in England, Marot and Bèze and Philippe Desportes in France, for example, all produced metrical versions of the complete Psalms. The first, partial, collection of the famous Metrical Psalms by Sternhold and Hopkins appeared in 1549 (complete version, 1562), the same year as Wyatt's Penitential Psalms and also Crowley's Psalter of David, the first complete English metrical translation, and of course of the first Edwardian Prayer Book.

11 The Tudor courtier and poet Sir Thomas Wyatt composed his powerful dramatic paraphrase of the seven psalms at the very height of the Henrician reforms. Certain psalms commonly called the VII penitential psalms, drawn into English meter was published at the end of the year 1549, seven years after the poet's death at the age of thirty-nine, with a prefatory sonnet by Wyatt's friend and fellow-poet, Henry Howard, Earl of Surrey; Surrey himself wrote a splendid verse paraphrase of Psalm 51 (before being beheaded on 19 January 1547, another victim of Henry's last paroxysm of vengeance against the Howard clan, just nine days before the bloated tyrant himself died). Some or all of the Penitentials might be included in seemingly random selections of psalms. Such is the volume compiled by Sir John Croke about 1547, containing thirteen psalms, including all seven of the Penitentials, and the book of Ecclesiastes. Often, like Surrey, a poet would paraphrase a single, isolated Penitential Psalm. The Protestant playwright and polemicist John Bale included a verse rendition of the De profundis (Psalm 130) in his pamphlet An Expostulation or Complaint against the Blasphemies of a Frantic Papist of Hampshire (c.1552). Another notable example is the Elizabethan poet George Gascoigne's striking version of the same psalm. Gascoigne, like Wyatt, provides a dramatic frame in which to set his psalm paraphrase. ${ }^{10}$ Among the many others in England who paraphrased one or more of the Penitentials in the sixteenth and seventeenth centuries are William Byrd, King James I, Sir John Davies, Thomas Carew, Joseph Hall and John Milton. John Davies of Hereford (not Sir John Davies) published his The Doleful Dove: or, Davids 7. Penitentiall Psalmes, somewhere paraphrastically turned into Verse in 1612. The most curious of all is certainly William Hunnis's massive and evidently hugely popular Seven Sobs of a Sorrowful Soule for Sinne: Comprehending those seven Psalmes of the Princelie Prophet David, commonlie called Poenitentiall; framed into a forme of familiar praiers, and reduced into meeter, which appeared in 1583 and was reissued in 1587, $1589,1597,1600,1604$, etc. until 1629. As might be expected, and feared, from the work's 
title, it is a staggering, monumental production: each of the seven psalms is divided into two or more 'parts', each part 'reduced' into anything from fifteen to fifty-four rhymed fourteener couplets (fourteener: archaic English meter, a heptameter line of seven iambic feet, or fourteen syllables). Psalm 51 (Miserere mei) has five parts, and at 300 fourteensyllable lines, is clearly the centrepiece and centre of gravity of the entire work. The grand total of 1,210 heptameter lines-printed however as short alternating eight- and six-syllable lines-occupy 85 pages in small octavo. What might have been the greatest of all, poetically speaking, is lost: a paraphrase of the Penitential Psalms is listed among the works of Edmund Spenser. During the same period and after, many composers of the first rank set one or all of the Penitentials, from Andrea Gabrieli, Lassus, Byrd, Dowland and Schütz, to Locke, Blow, Purcell, Bach and Handel, to Mozart, Mendelssohn and Brahms.

But it is the place of the Penitential Psalms within the new Church of England services for Ash Wednesday, the first day of Lent, that is my subject. In 1549, the service for 'the first day of Lent, commonly called Ash Wednesday' begins 'After mattens ended, the people being called together by the ringing of a bell, and assembled in the church; the English litany shall be said after the accustomed manner, which ended, the priest shall go into the pulpit and say thus: 'Brethren, in the primitive church there was a godly discipline ...'. In other words, exactly the text that would be reproduced in subsequent versions up to and including 1662, complete with the responsive maledictions; the latter were not part of the medieval rite, but a Cranmerian innovation. On the other hand, this is the only mention of bell-ringing in 1549, whereas the medieval services were full of bells; 1552 and 1559 both retain the bell. In January 1549, however, Cranmer announced to his bishops that Ash Wednesday ashes, as well as Candlemas candles and Palm Sunday palms would henceforth be banned. ${ }^{11}$ Then follows the rubric: 'Then shall they all kneel upon their knees. And the priests and clerks kneeling where they are accustomed to say the litany, shall say this psalm: Miserere mei deus'. The English text in Coverdale's Great Bible version follows. The Miserere mei, Psalm 51, is the sole survivor in the new vernacular Ash Wednesday service, of the seven Penitential Psalms recited in Latin by the clergy in the Sarum Use. It would remain so throughout the revisions of the following century. Despite the radical paring away of ritual-the Sarum text specifies which vestments in which colours shall be worn, where priest, deacon and subdeacon are to stand and where to kneel, where the acolyte who holds the sackcloth banner shall be positioned; the clergy now kneeling rather than prostrating themselves; the absence of ashes, etc-a kernel, albeit a major one, the central psalm of the famous seven, survives. But in fact there is more. Turning to chapter iv of the 1549 book, 'The Introits, Collects, Epistles and Gospels to be used ... through the year, with proper Psalms and Lessons, for divers feasts and days', we find a special Psalm, a Collect, an Epistle and a Gospel for Communion on the first day of Lent, that is preceding the special Ash Wednesday service. The prescribed psalm is 6, the first of the Penitentials; the Epistle and Gospel are respectively, from Joel 2 and Matthew 6, that is the very texts set for Ash Wednesday in the Sarum Missal. Furthermore, two more of the Penitentials are set for Communion on the first and second Sundays in Lent: 32, Beati quorum for the first, and 130 , De profundis for the second. Thus four of the seven psalms are prescribed in the new English Prayer Book for Ash Wednesday and the first two Sundays in Lent; there are rather more traces of the old rites in the new than at first appears.

In 1552, despite radical revision of many parts of the book, the rubrics and text for Ash Wednesday remain the same, with Psalm 51 said by the priests and clerks kneeling. As has been noted, the title becomes 'A Commination against Sinners', following one of the 
recommendations made by Martin Bucer in a commissioned report on 1549. But 1552 specifies for the first day of Lent, in the section of Collects, Epistles and Gospels for certain feasts throughout the year, for the Epistle Joel 2.12-19, and for the Gospel Matthew 6.16-21, that is, again, the same texts specified for Ash Wednesday in the Sarum Missal and in 1549. They remain in 1662 and thus to this day, the Epistle and Gospel set for Ash Wednesday. The Introits are omitted entirely in 1552, so those other Penitential Psalms for the first two Sundays in Lent are not mentioned. Another important change in 1552 concerned the Litany, which became a separate, stationary performance preceding the Eucharist, and no longer a procession. This left only a small Easter procession, and the Ash Wednesday service as sole survivors of the numerous medieval processions, which had required an entire separate service book, the Processional. It is also enjoined in 1552 that the Litany shall be said on Sundays, Wednesdays and Fridays, hence of course on Ash Wednesday, as is seen in the rubric 'After Morning Prayer, the Litany ended according to the accustomed manner ...'. As we know, the 1552 Prayer Book had hardly been put in use, late in the year, when Mary succeeded to the throne a few months later and it was banned, to be revived more or less intact when Elizabeth in turn succeeded in 1558.

The Elizabethan Book of Common Prayer was promulgated by the 1559 Act of Uniformity, following the five-year Marian interlude, in which the medieval rite had been restored, along with clerical vestments, processions, images, saints' days and the Roman services. '1559 is a close relation to 1552, with small yet significant changes, e.g. to the words of distribution of the Eucharist and to the Litany', according to Brian Cummings in the commentary to his recent edition of the texts of 1549,1559 and $1662 .{ }^{12}$ The Commination service remained identical to that in 1549 and 1552. The licence granted by Bucer's addition in 1552, recommending its use 'at diverse times in the year' seems to have resulted in its being used, in Elizabeth's reign, on several Sundays before Easter (in continuation of the Lenten theme of penitence) and at other times, on Sundays before Whitsun and Christmas, for example (Cummings, 744). The so-called 'Hampton Court' revision of 1604 saw no changes to Ash Wednesday services or to the prescriptive use of the Penitential Psalms. The latter simply had their places in numerical order among the others in the monthly calendar of daily Psalm readings, some in the morning, some in the evening.

So we come at last to 1662 and the Restoration Prayer Book. The earliest versions of the Prayer Book had succeeded one another with dizzying rapidity, in one of the most dizzying and disruptive periods in English history: consider the mere decade, little more, from the death of Henry VIII in 1547 to the succession of his third heir, Elizabeth, in 1558. First issued in 1549, hastily revised and reissued in 1552, only to be supplanted and banned almost immediately by Mary in 1553, then restored in one of the first acts of her half-sister's reign in 1559, the Book of Common Prayer had a childhood as perturbed as those of the sister queens who played such crucial roles in its varied fortunes. Banned by a Catholic queen in 1553, the Book of Common Prayer in its Elizabethan-Jacobean revision was in its turn banned by the Puritan Long Parliament less than a century later (1645). Finally restored in 1662, it has remarkably survived 350 years, never fully supplanted by late-twentieth-century alternatives. What was left then, what is left now, of its predecessors' prescriptions for the use of the Penitential Psalms in the services for Ash Wednesday? Of course the glorious Coverdale Psalter is integrated in its entirety for the first time in 1662. So familiar had its language become that it could not be replaced, even by the King James Version of 1611; it still has not been. ${ }^{13}$ 

pronounced by 'the people' after each, except that the first has lost most of its iconoclastic fervour: 'Cursed is the man that maketh any carved or molten image', while clear, is less emphatic than $1552 / 59$ 's 'Cursed is the man that maketh any carved, or molten image, an abomination to the Lord, the work of the hands of the craftsman, and putteth it in a secret place to worship it'. In the same vein, 'worshipers of images' in the final summary curse has become merely 'idolaters'; they are lumped together with fornicators, adulterers, slanderers, drunkards, extortionists and the like. The summoning bell has been lost, but the people are to kneel as before, while the priest and the clerks, also kneeling, say the ever-present Miserere mei, in Coverdale's version of course. Even the parenthetical-'which thing is much to be wished'-i.e., that the discipline of open penance, as in Sarum, 'may be restored again' remains from 1549, as it had in all of the intervening revisions; another little touch of Cranmer's, crouching there in parentheses through the centuries.

1 must conclude, and we have come full circle. At the end of a section entitled 'Proper Lessons and Psalms to be read at Morning and Evening Prayer on the Sundays and other Holidays throughout the year', under the rubric 'Proper Psalms on certain days', in small print at the bottom of a page in modern editions, we find under Ash Wednesday, for Matins, Psalms 6, 32 and 38; and for Evensong, Psalms 102, 130 and 143. In 1559, this section, under the same heading, prescribes psalms only for Christmas, Easter, Ascension Day and Whitsunday; Ash Wednesday and Good Friday were added in $1662 .{ }^{14}$ With Psalm 51, the Miserere mei, proper to the Ash Wednesday office as always, we have once again the full complement of the seven Penitential Psalms, in order, as in the medieval rite, though distributed over the three services; but the ensemble is enhanced, as they are distributed three and three, on either side of the central Miserere mei. No doubt the 1662 revisers too admired the elegance of that fearful symmetry perceived so long ago in what are still known today as the Penitential Psalms.

\section{NOTES}

1. Quoted in Evan Daniel, The Prayer-Book: Its History, Language, and Contents, sixteenth edition (London, 1892), 219. I assume that it is this Gratian rather than the fourth-century Christian Roman emperor of the same name, who was the author of the description.

2. See K.A. Haworth, The Use of Sarum: The Worship and Organisation of Salisbury Cathedral in the Middle Ages (Salisbury, 1973).

3. The Sarum Missal, Done into English by A.H. Pearson (London, 1884), 52. Sexts (or Sext) is the office for the sixth hour in the day, counting from six a.m. (i.e., noon).

4. The Expositio psalmorum of Cassiodorus (mid-sixth century) was indebted to the Enarrationes in psalmos of Augustine. Augustine is said to have asked that four of the psalms be prominently posted on the walls of his chamber during his final illness. His favourite was Psalm 32, Beati quorum ('Blessed is he whose unrighteousness is forgiven'). 
5. In his classic commentary, Artur Weiser says simply: 'Of the seven penitential psalms Psalm 51 is the most important one. It demonstrates the essence of true penitence' (The Psalms: A Commentary, trans. Herbert Hartwell [London: SCM Press, 1962], 401).

6. See The Discarded Image: An Introduction to Medieval and Renaissance Literature (Cambridge, 1964), 10-12. Lewis makes only passing references to or quotes very briefly from the Penitential Psalms in his classic Reflections on the Psalms (New York, 1958). A few further brief quotations occur in 'The Psalms', in Christian Reflections, ed. Walter Hooper (Grand Rapids, 1957), 114-28.

7. "Les sept psaumes allégorisés" of Christine de Pisan: A Critical Edition, ed. Ruth Ringland Rains (Washington, 1965); and see Enid McLeod, The Order of the Rose: The Life and Ideas of Christine de Pizan (London, 1976), pp. 147-8. The Seven Psalms: A Commentary on the Penitential Psalms translated from French into English by Dame Eleanor Hull, ed. Alexandra Barratt, Early English Text Society 307 (Oxford, 1995). Hull is the first English woman translator whose name is known.

8. The seven Penitentials, with Rolle's commentary, were selected and edited by Geraldine Hodgson (London, 1928).

9. Saint John Fisher, Exposition of the Seven Penitential Psalms in Modern English, intro. Anne Barbeau Gardiner (San Francisco, 1998).

10. 'Gascoigne's De Profundis' itself was erroneously omitted from the 1573 collection of his works, A Hundreth Sundrie Flowres, though the prefatory sonnet was included; the psalm was restored in the collected works of 1575. See the edition by G.W. Pigman III (Oxford, 2000), lxii, 290-93. Psalm 130 is the shortest of the Penitentials; Psalm 102, with 28 verses, is the longest.

11. Diarmaid MacCulloch, Thomas Cranmer: A Life (New Haven and London: Yale University Press, 1996), 383.

12. Brian Cummings, ed., The Book of Common Prayer: The Texts of 1549, 1559, and 1662 (Oxford, 2011), 722.

13. In October 1789, shortly after the end of the War of Independence, the Convention of the Protestant Episcopal Church in the United States of America ratified a Book of Common Prayer, closely based on 1662. The Psalter is Coverdale's, very slightly edited here and there. The Commination is replaced by 'A Penitential Office for Ash Wednesday': there are no maledictions; both clergy and people, kneeling, say the inevitable Miserere mei, Deus in Coverdale's version. A 'Selection of Psalms' at the beginning of the book, lists twenty-eight groups of Psalms on various themes; number 26 is 'Penitential Psalms', with the established seven. Under 'Psalms and Lessons for the Christian Year', for Ash Wednesday are prescribed, for Morning Prayer, Psalms 32 and 143, for Evening Prayer, 102 and 130; Penitentials all, though not all of them.

14. Unfortunately, Cummings's excellent edition is misleading on this point: a note next to the chapter title, 'Proper Psalmes and lessons ...' on the contents page (101) of his edition of 1559, directs the reader to 'see 1662'. But as has just been observed, they are not the same: only four feast days are included in 1559, not six as in 1662.

\section{ABSTRACTS}

This paper traces the presence and the particular uses made of the seven Penitential Psalms in services for Ash Wednesday and related occasions, in successive versions of the Book of Common Prayer, from 1549 to 1662 . A brief history of the Seven Psalms and their place in pre-Reformation liturgy, as set down notably in the Use of Sarum (though they were prescribed in ecclesiastical 
treatises even earlier), precedes a close examination of the evolution of their use in the first four Anglican prayer books, and in the earliest American (Episcopalian) version (1789). It is notable that the seven Psalms were included, in various groupings and at various points within the Ash Wednesday or Lenten Sunday services, throughout the period of the early revisions of the Prayer Book. The striking symmetry of the Latin incipits of the seven Psalms, and their perceived appropriateness for the services of penitence on Ash Wednesday and other services in Lent, continued to command the attention and respect of revisers of the successive versions of the Book of Common Prayer, as it had done for their predecessors since the early Middle Ages.

Les sept psaumes pénitentiels font partie des offices pour le mercredi des Cendres dans toutes les versions du Book of Common Prayer, de 1549 à 1662. Une brève histoire des sept psaumes et leur place dans la liturgie médiévale, en particulier dans le rite de Salisbury (même si des traités ecclésiastiques antérieurs les prescrivent déjà), précède ici l'examen de l'évolution de leur usage dans les quatre premières versions du Book of Common Prayer-1549, 1552, 1559, 1662-ainsi que dans la première édition américaine (1789). Il est remarquable que, de révision en révision, les sept psaumes aient toujours été incorporés aux liturgies du mercredi des Cendres ou des dimanches de Carême, tout au long des XVIe et XVIIe siècles. Sans doute, la symétrie frappante des incipits latins des sept psaumes et l'adéquation de leur contenu au temps liturgique de la pénitence avaient exercé la même séduction sur les rédacteurs des versions successives du Book of Common Prayer que sur leurs prédécesseurs depuis le haut Moyen Age.

INDEX

Keywords: Book of Common Prayer, Penitential Psalms, liturgy, Lent

\section{AUTHOR}

\section{CHARLES WHITWORTH}

Université de Montpellier 3 